\title{
CONCENTRATION OF WATER POLLUTION INDICATORS BACTERIA IN SIRIH PADANG SUMATERA BARAT
}

\author{
Gilang Ferdana $^{1}$, Nursyirwani ${ }^{1}$, Bintal Amin ${ }^{1}$ \\ ${ }^{1}$ Department of Marine Science, Faculty of Fisheries and Marine Universitas Riau, Pekanbaru \\ *gilangferdana@gmail.com
}

\begin{abstract}
This research was conducted in October 2019 in the waters of Sirih Bay Padang, West Sumatra Province. The objective of this research aimed was to determine the number of bacterial cells as an indicator of water pollution (total coliform and Escherichia coli) in the waters of Sirih Bay, Padang. The method used in this study was a survey method. Polluted waters in Sirih Bay as sampling location was divided into 3 stations, namely the PLTU area (St. I), near BPBALP Padang (St. II) and a residential area (St. III). Isolation of total coliform and fecal coliform bacteria was carried out by assumption and affirmation tests which were further identified and carried out physiological and biochemical properties. The results showed the total number of coliforms in Sirih Bay waters in the assertion test using BGLB media ranged from 75-460 MPN/ml. This indicates the existence of pollution of coliform bacteria in these waters based on the Decree of the State Minister of Environment No. 51 of 2004 concerning Sea Water Quality Standards, the maximum level of total coliform bacteria is 1000 MPN / $100 \mathrm{ml}$. The results of this study indicated that the waters of Sirih Bay are considered to be in poor condition
\end{abstract}

Keywords: Total coliform, Escherichia coli, Teluk Sirih

\section{PENDAHULUAN}

Kawasan pesisir Teluk Sirih, Bungus yang terletak di selatan Kota Padang memegang peranan penting bagi Provinsi Sumatera Barat khususnya Kota Padang. Banyaknya pabrik-pabrik dan adanya pemukiman penduduk di sekitar wilayah pesisir sepanjang pantai Kota Padang menyebabkan beberapa wilayah perairan tersebut menjadi tercemar akibat buangan limbah pabrik maupun aktivitas penduduk. Salah satu industri yang berada di sekitar perairan adalah Pembangkit Listrik Tenaga Uap (PLTU) yang berada di tepi Teluk Sirih, Bungus Padang.

Ketersediaan sumber air yang berkualitas baik sangat sedikit dikarenakan kurangnya kepedulian masyarakat terhadap pencemaran lingkungan perairan. Salah satu pencemaran secara mikrobiologis yang terjadi di perairan yaitu dengan melimpahnya bakteri coliform, dan mikroorganisme yang mengindikasikan adanya pencemaran oleh bakteri Escherichia coli. Untuk itu perlu adanya pemeriksaan kandungan bakteri coliform serta $E$. coli di suatu perairan yang digunakan untuk pengelolaan perairan tersebut serta pengelolaan pembuangan limbah untuk kegiatan industri maupun kegiatan rumah tangga. Semakin tinggi kandungan coliform di suatu perairan, maka semakin tinggi pula kehadiran bakteri patogen. Hal ini dapat menyebabkan gangguan kesehatan pada manusia akibat dari perairan tersebut apabila sumber air ini digunakan untuk kegiatan-kegiatan manusia. Selain itu 
bakteri ini juga bisa mencemari biota-biota yang ada di dalam perairan tersebut.

Adanya aktivitas penduduk dan PLTU dapat menyebabkan perairan Teluk Sirih secara langsung maupun tidak langsung akan tercemar oleh bakteri pencemar perairan. Kondisi ini menarik untuk dikaji lebih mendalam disebabkan beberapa kondisi lapang menunjukkan secara fisik kondisinya baik, akan tetapi secara biologis menunjukkan kondisi sebaliknya.

Teluk Sirih merupakan salah satu perairan yang terletak di Desa Teluk Sirih Kecamatan Bungus Teluk Kabung, Kota Padang. Kecamatan ini berada dalam jarak $12 \mathrm{~km}$ dari pusat kota. Sebagai salah satu kawasan yang memiliki potensi alam, Pemerintah Pusat dan Daerah telah membangun sebuah Pembangkit Listrik Tenaga Uap (PLTU) di Teluk Sirih. Dengan adanya kawasan PLTU ini mengakibatkan beberapa wilayah perairan di Teluk Sirih menjadi tercemar akibat pembuangan limbah-limbah industri. Hal ini tentunya akan mengganggu biota yang ada di perairan tersebut. Akibat pembuangan tersebut tentunya juga terdapat beberapa bakteri-bakteri yang menjadi indikator apakah perairan tersebut dikategorikan sebagai perairan tercemar atau tidak.

Berdasarkan penelitian yang telah dilakukan [1], jumlah bakteri yang didapat di ekosistem terumbu karang Pulau Pramuka Kepulauan Seribu, DKI Jakarta berkisar anta 9 - >1.100 MPN/100ml. Pada penelitian Anggraini et al., (2013) dari hasil uji dengan menggunakan metoda MPN ditemukan jumlah bakteri coliform di Sungai Batang Arau Padang adalah 1.100/ $100 \mathrm{ml}$ dan $\geq 2400 / 100 \mathrm{ml}$. [2] bahwa pembuangan limbah organik yang berasal dari aktivitas masyarakat dapat meningkatkan organisme patogen di perairan.

Masalah dalam penelitian ini adalah adanya aktivitas penduduk dan PLTU di Teluk Sirih Kota Padang dapat menyebabkan terjadinya pencemaran biologi di perairan teluk tersebut. Secara biologi pencemaran perairan dapat dilihat dari keberadaan bakteri indikator pencemaran yaitu total coliform dan fecal coliform. Namun belum diketahui berapa kandungan bakteri indikator pencemaran di perairan Teluk Sirih.

\section{METODE PENELITIAN Waktu dan Tempat}

Penelitian ini dilaksanakan pada bulan Oktober 2019 di perairan Teluk Sirih Padang Provinsi Sumatera Barat (Gambar 1). Selanjutnya sampel yang didapat dianalisis di Laboratorium Mikrobiologi Laut Jurusan Ilmu Kelautan Fakultas Perikanan dan Kelautan Universitas Riau

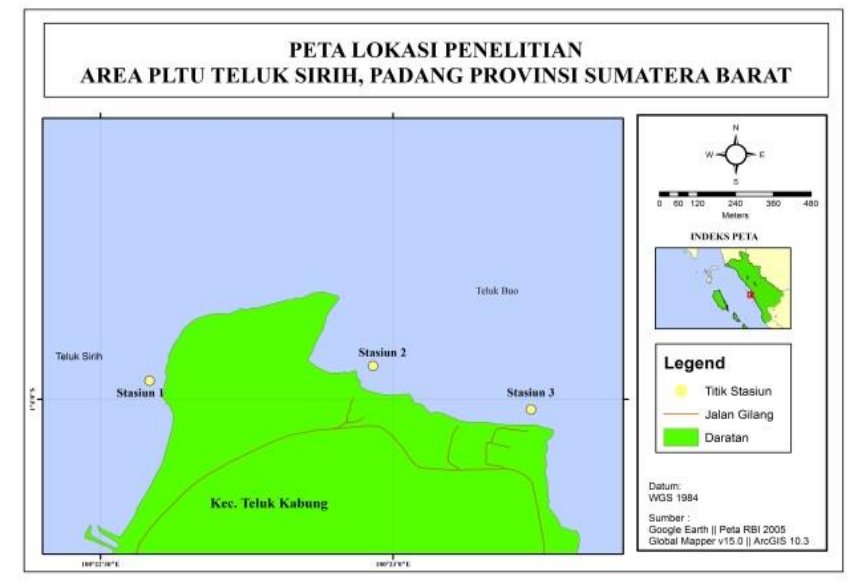

Gambar 1. Peta Lokasi Penelitian 


\section{Metode Penelitian}

Metode yang digunakan dalam penelitian ini adalah metode survei. Parameter kualitas perairan yang diukur yaitu suhu, salinitas, dan $\mathrm{pH}$. Pengukuran dilakukan sebanyak 3 kali pengulangan. Lokasi penelitian dibagi menjadi 3 stasiun, yaitu Stasiun I di sekitar kawasan PLTU, Stasiun II di dekat BPBALP Padang, dan Stasiun III di kawasan pemukiman penduduk.

\section{Prosedur Penelitian \\ Sterilisasi Alat}

Alat-alat yang digunakan disterilkan menggunakan autoclave pada suhu $121^{\circ} \mathrm{C}$ dengan tekanan 2 atm selama 15 menit. Jarum ose dan pinset disterilkan dengan cara pemijaran. Media yang digunakan juga disterilisasi menggunakan autoclave [3].

\section{Analisis Bakteri $E$. coli}

Analisis bakteri E. coli dilakukan dengan menggunakan metode Most Probable Number (MPN) seri 3 tabung berdasarkan BSNI No. 2897:2008. Pengujian dilakukan melalui uji pendugaan (persumtive test), uji penegasan (comfirmed test), dan uji pelengkap (completed test). Sebelum uji-uji tersebut dilakukan, sampel terlebih dahulu diencerkan.

Berdasarkan hasil tiap-tiap pengenceran, uji pendugaan dilakukan dengan menggunakan media media LB (Lactose Broth) yang dilengkapi tabung Durham terbalik. Diinkubasi pada suhu $35^{\circ} \mathrm{C}$ selama 24 jam. Apabila hasil uji pendugaan positif, maka selanjutnya dilakukan uji penegasan. Uji ini menggunakan media selektif yang dapat ditumbuhi oleh bakteri coliform yaitu BGLB (Brillian Green Lactose Broth) yang berisi tabung Durham terbalik dan diinkubasi pada suhu $37^{\circ} \mathrm{C}$ selama 24 jam. Hasil positif pada ke dua uji ditunjukkan sebagai angka rujukan pada daftar MPN (Most Probable Number).

Tahapan selanjutnya hasil positif yang terdapat pada tabung diinokulasi ke dalam media Eosin Methylene Blue Agar (EMB) dengan metode gores diinkubasi pada suhu $37^{\circ} \mathrm{C}$ selama 24 jam. Sebelum melakukan pengamatan morfologi, bakteri E. coli dihitung terlebih dahulu dengan menggunakan rumus :

$$
\text { Jumlah bakteri }=\frac{\text { Jumlah koloni bakteri }}{\text { Faktor pengencer } \times 0,1}
$$

\section{Pengamatan Morfologi Bakteri}

Pengamatan morfologi koloni meliputi bentuk, ukuran, elevasi tepian dan warna koloni yang diamati secara pada langsung pada sampel yang telah murni dan terpisah [4]. Sedangkan uji sifat fisiologi dan biokimia bakteri terdiri dari pewarnaan gram, uji katalase, uji motilitas, uji indol, uji sitrat, uji methyl red (MR Test), uji penggunaan gula, dan uji sulfida $\left(\mathrm{H}_{2} \mathrm{~S}\right)$.

\section{HASIL DAN PEMBAHASAN Parameter Kualitas Perairan}

Hasil pengukuran parameter kualitas perairan di lokasi penelitian berupa suhu berkisar antara $30-31^{\circ} \mathrm{C}$, salinitas berkisar antara $20-21 \%$ dan $\mathrm{pH}$ bernilai 6. Hasil pengukuran parameter kualitas perairan di kawasan perairan Teluk Sirih dapat dilihat pada Tabel 1.

Tabel 1. Hasil Pengukuran Parameter Kualitas Perairan

\begin{tabular}{cccccc}
\hline \multirow{2}{*}{ Stasiun } & \multicolumn{2}{c}{ Titik Koordinat } & \multirow{2}{*}{ Suhu $\left({ }^{\circ} \mathbf{C}\right)$} & Salinitas (\%o) & \multirow{2}{*}{ pH } \\
\cline { 2 - 3 } & BT & $-1,066472$ & 31 & 20 & 6 \\
I & 100,376434 & $-1,066013$ & 30 & 20 & 6 \\
II & 100,382571 & $-1,067201$ & 30 & 21 & 6 \\
\hline
\end{tabular}




\section{Densitas Bakteri $E$. coli}

Bakteri indikator pencemaran perairan rekreasi pantai yaitu fekal coliform, fekal streptococus dan patogen [5]. Bakteri coliform ditemukan dalam jumlah yang cukup banyak pada semua sampel penelitian. Berdasarkan hasil penelitian yang telah dilakukan uji pendugaan dengan menggunakan media LB (Tabel 2), total coliform di perairan Teluk Sirih berkisar antara 93-1.100 MPN/ml.

Tabel 2. Data Hasil Uji Pendugaan dengan media LB

\begin{tabular}{ccccccc}
\hline \multirow{2}{*}{ Stasiun } & Sampel & \multicolumn{2}{c}{ Jumlah Tabung Positif } & \multirow{2}{*}{ MPN/ml } & \multirow{2}{*}{ Rata- Rata } \\
\cline { 2 - 5 } & $\mathbf{1 0}^{-1}$ & $\mathbf{1 0}^{-2}$ & $\mathbf{1 0}^{-3}$ & & \\
\hline I & 1 & 3 & 2 & 0 & 93 & \multirow{2}{*}{224,33} \\
& 2 & 3 & 2 & 3 & 290 & \\
\hline \multirow{2}{*}{ II } & 3 & 3 & 2 & 3 & 290 & \\
& 1 & 3 & 2 & 1 & 150 & \\
& 2 & 3 & 2 & 3 & 290 & \\
\hline \multirow{2}{*}{ III } & 3 & 3 & 2 & 3 & 290 & \\
& 1 & 3 & 3 & 2 & 1.100 & \\
& 2 & 3 & 3 & 2 & 1.100 & \\
\hline
\end{tabular}

Tabel 3. Data Hasil Uji Penegasan dengan media BGLB

\begin{tabular}{|c|c|c|c|c|c|c|}
\hline \multirow[b]{2}{*}{ Stasiun } & \multirow{2}{*}{ Sampel } & \multicolumn{3}{|c|}{ Jumlah Tabung Positif } & \multirow{2}{*}{ MPN/ml } & \multirow{2}{*}{ Rata- Rata } \\
\hline & & $10^{-1}$ & $10^{-2}$ & $10^{-3}$ & & \\
\hline \multirow[t]{3}{*}{$\mathrm{I}$} & 1 & 3 & 1 & 1 & 75 & \multirow{3}{*}{191,67} \\
\hline & 2 & 3 & 2 & 3 & 290 & \\
\hline & 3 & 3 & 2 & 2 & 210 & \\
\hline \multirow[t]{3}{*}{ II } & 1 & 3 & 2 & 0 & 93 & \multirow{3}{*}{151} \\
\hline & 2 & 3 & 2 & 1 & 150 & \\
\hline & 3 & 3 & 2 & 2 & 210 & \\
\hline \multirow[t]{3}{*}{ III } & 1 & 3 & 3 & 1 & 460 & \multirow{3}{*}{376,67} \\
\hline & 2 & 3 & 3 & 1 & 460 & \\
\hline & 3 & 3 & 2 & 2 & 210 & \\
\hline
\end{tabular}

Selanjutnya, dilakukan uji penegasan dengan menggunakan media BGLB (Tabel 3) dengan menggunakan seri 3 tabung yang berkisar antara 75-460 MPN/ml. Hal ini mengindikasikan adanya pencemaran kelompok bakteri coliform di perairan tersebut. Berdasarkan Keputusan Menteri Negara Lingkungan No. 51 Tahun 2004, level maksimum total bakteri coliform yang diperbolehkan yaitu 1000 MPN/100 ml, sedangkan level maksimum E. coli dalam Kep-82/MENKLH/2001 adalah 100 MPN/ $100 \mathrm{ml}$. Hasil penelitian tersebut menandakan bahwa perairan Teluk Sirih termasuk ke dalam perairan yang kurang baik. Tingginya nilai MPN coliform di perairan Teluk ini disebabkan oleh beberapa faktor, seperti aktivitas masyarakat yang membuang limbah langsung ke perairan, dan limbah dari kegiatan industri di sekitaran PLTU dan BPBALP Padang.

Bakteri E. coli yang diisolasi dengan menggunakan uji pendugaan dan uji penegasan memperoleh jumlah koloni Bakteri E. coli menunjukkan bahwa jumlah koloni terbanyak berada pada sampel S2 dengan jumlah bakteri sebanyak 4,4 x $10^{5}$ CFU/ml, sedangkan jumlah koloni terendah pada sampel S4 dengan jumlah bakteri 
sebanyak $1,1 \times 10^{4} \mathrm{CFU} / \mathrm{ml}$. Berdasarkan hasil Uji ANOVA terhadap perbedaan konsentrasi bakteri indikator pencemaran perairan (total coliform dan E. coli) di perairan Teluk Sirih Padang Sumatera Barat didapatkan hasil nilai signifikan yaitu
0,760 (>0,05), yang berarti tidak ada perbedaan konsentrasi bakteri indikator pencemaran perairan (total coliform dan E. coli) di perairan Teluk Sirih Padang Sumatera Barat.

Tabel 4. Jumlah Bakteri E. coli

\begin{tabular}{|c|c|c|}
\hline Stasiun & Sampel & Jumlah Bakteri (CFU/ml) \\
\hline \multirow{6}{*}{ Stasiun I } & S 1 & $3,4 \times 10^{5}$ \\
\hline & S 2 & $4,4 \times 10^{5}$ \\
\hline & S 3 & $2,8 \times 10^{5}$ \\
\hline & S 4 & $1,1 \times 10^{4}$ \\
\hline & S 5 & $1,8 \times 10^{4}$ \\
\hline & S 6 & $3 \times 10^{4}$ \\
\hline \multirow{6}{*}{ Stasiun II } & S 7 & $2,1 \times 10^{5}$ \\
\hline & S 8 & $2 \times 10^{5}$ \\
\hline & S 9 & $2,2 \times 10^{5}$ \\
\hline & S 10 & $2,7 \times 10^{4}$ \\
\hline & S 11 & $2,6 \times 10^{5}$ \\
\hline & S 12 & $1,5 \times 10^{5}$ \\
\hline \multirow{6}{*}{ Stasiun III } & S 13 & $2,2 \times 10^{4}$ \\
\hline & S 14 & $1,7 \times 10^{5}$ \\
\hline & S 15 & $2,3 \times 10^{5}$ \\
\hline & S 16 & $2,9 \times 10^{5}$ \\
\hline & S 17 & $4,5 \times 10^{4}$ \\
\hline & S 18 & $3,3 \times 10^{4}$ \\
\hline
\end{tabular}

Stasiun I memiliki jumlah Bakteri E. coli tertinggi yaitu $4,4 \times 10^{5} \mathrm{CFU} / \mathrm{ml}$ dan terendah yaitu $1,1 \quad$ x $10^{4} \mathrm{CFU} / \mathrm{ml}$. Tingginya jumlah Bakteri E. coli diperairan ini juga disebabkan oleh pembuangan limbah di sekitaran PLTU yang mengeluarkan limbah panas. Bakteri dapat berkembang biak dalam kondisi tersebut. Pada saat pengukuran suhu di lokasi penelitian didapatkan nilai suhu sebesar $31^{\circ} \mathrm{C}$. Hal ini juga diperkuat oleh [6] suhu pertumbuhan E. coli adalah $37^{\circ} \mathrm{C}$, tetapi juga dapat tumbuh pada kisaran temperatur $15-45^{\circ} \mathrm{C}$. Nilai salinitas di Stasiun I yaitu 20\%. [7] menyatakan bahwa salinitas optimal yang baik untuk pertumbuhan bakteri laut adalah antara 25-40 ppt. Nilai $\mathrm{pH}$ di Stasiun I yaitu 6. Menurut [8], pH optimum untuk bakteri adalah 6,5 dan 7,5. Jika bakteri berada di lingkungan dengan
pH yang tidak sesuai, maka pertumbuhannya akan terhambat.

Stasiun II memiliki jumlah Bakteri E. coli tertinggi yaitu $2,6 \times 10^{5} \mathrm{CFU} / \mathrm{ml}$ dan terendah yaitu $2,7 \quad$ x $10^{4} \mathrm{CFU} / \mathrm{ml}$. Tingginya jumlah Bakteri E. coli diperairan ini juga disebabkan oleh pembuangan limbah oleh BPBALP seperti sisa-sisa pakan di sekitaran keramba. Keberadaannya sering ditopang oleh semakin meningkatnya unsur hara di dalam perairan, bila jumlah total bakteri di perairan sangat tinggi (baku mutu $1000 \mathrm{CFU} / \mathrm{ml}$ ) maka akan semakin meningkatkan probabilitas keberadaan bakteri khususnya bakteri patogen [9].

Pada pengukuran kualitas air, suhu yang didapat di Stasiun II ini adalah $30^{\circ} \mathrm{C}$. Menurut [10], pada temperatur sekitar $30^{\circ} \mathrm{C}$ merupakan temperatur yang baik bagi 
kehidupan bakteri patogen yang berasal dari hewan maupun tubuh manusia. Nilai salinitas di Stasiun II sebesar 20\%o. Tidak ada perbedaan salinitas antar stasiun. Kisaran salinitas yang diperoleh dalam penelitian ini sangat mendukung pertumbuhan bakteri. Beberapa parameter penting yang berpengaruh terhadap pertumbuhan bakteri adalah suhu dan salinitas [11]. Sedangkan nilai $\mathrm{pH}$ yang didapat bernilai 6. Menurut [12] bakteri laut dapat tumbuh pada $\mathrm{pH} 6,5-8,5$ namun pertumbuhan optimumnya 7,2-8,5.

Stasiun III memiliki jumlah Bakteri E. coli tertinggi yaitu $2,9 \times 10^{5} \mathrm{CFU} / \mathrm{ml}$ dan terendah yaitu 2,2 x $10^{4} \mathrm{CFU} / \mathrm{ml}$. Tingginya jumlah Bakteri E. coli diperairan ini disebabkan oleh pembuangan limbah oleh masyarakat. Hasil pengukuran suhu di Stasiun III yaitu $30^{\circ} \mathrm{C}$. Menurut [13] kondisi yang dapat menunjang pertumbuhan bakteri coliform adalah 12$44^{\circ} \mathrm{C}$. Nilai salinitas di Stasiun III tidak jauh berbeda dengan Stasiun I dan Staisiun II yaitu sebesar 21\%o. Kondisi suhu dan salinitas di perairan Teluk Sirih dalam kisaran normal untuk untuk daerah tropis [14] sehingga cocok untuk tumbuh kembang bakteri, termasuk jenis coliform. Nilai $\mathrm{pH}$ pada Stasiun III yaitu 6. Nilai $\mathrm{pH}$ di semua stasiun sama, dimana pada nilai tersebut bakteri coliform dapat tumbuh pada perairan Teluk Sirih.

Bakteri coliform merupakan salah satu jenis bakteri patogen. Bakteri patogen menjadi salah satu indikator kondisi lingkungan [15-16] yang sekaligus menunjukkan sumber utamanya yang berasal dari limbah rumah tangga dan adanya pembusukan secara alamiah [15]. Menurut [17] secara mikrobiologis, keberadaan bakteri coliform pada air dapat dijadikan penentu apakah air tersebut layak digunakan untuk keperluan tertentu seperti untuk air minum, perikanan, peternakan, pertanian dan lain-lain. Kelimpahan bakteri coliform di lokasi penelitian belum dapat dijadikan sebagai dasar menyimpulkan kondisi lingkungan perairan tercemar atau tidak, akan tetapi lebih sebagai indikator awal yang menunjukkan bahwa kondisi lingkungan mengalami penurunan secara biologis. Salah satunya dengan ditemukannya bakteri patogen, diantaranya adalah jenis coliform ini $[15,18]$.

\section{Pengamatan Morfologi dan Biokimia Bakteri E. coli}

Hasil isolasi bakteri yang ditanam pada media agar diperoleh 18 sampel yang kemudian dimurnikan. Pengamatan morfologi masing-masing sampel bakteri dapat dilihat pada Tabel 5.

Morfologi merupakan ilmu yang mempelajari tentang bentuk organisme, baik itu tumbuhan, hewan maupun organisme mikrobiologi seperti bakteri. Pada bakteri E. coli pengamatan yang dilakukan terhadap morfologinya adalah warna, bentuk koloni, tepian dan elevasi. Ada berbagai macam bentuk, tepian dan elevasi dari bakteri. Hasil dari pengamatan bakteri $E$. coli yang telah dilakukan adalah bakteri yang diisolasi pada media Eosin Methylene Blue Agar (EMB) memiliki warna hijau dan hitam dengan bentuk bulat, dengan tepian yang licin, dan memiliki elevasi (permukaan) mencembung. Hal ini sesuai dengan [19] bahwa bakteri E. coli yg tumbuh pada media Eosin Methylene Blue Agar (EMB) memiliki warna koloni hijau berinti mengkilat metalik dan bentuk bulat, elevasi mencembung, pinggiran bulat utuh. E. coli memiliki sifat antara lain: termasuk bakteri Gram negatif, bersifat motil, memfermentasi semua jenis gula, positif menghasilkan indol, positif uji methyl red, negatif uji Voges-Proskauer, dan negatif uji sitrat. Sedangkan hasil pengamatan uji biokimia. Bakteri E. coli dapat dilihat pada Tabel 6 
Tabel 5. Hasil Pengamatan Morfologi Sampel Bakteri E. coli

\begin{tabular}{|c|c|c|c|c|c|}
\hline Stasiun & Sampel & Warna & Bentuk Koloni & Tepian & Elevasi \\
\hline \multirow{6}{*}{ I } & S 1 & Hijau dan Hitam & Bulat & Licin & Cembung \\
\hline & S 2 & Hijau dan Hitam & Bulat & Licin & Cembung \\
\hline & S 3 & Hitam & Bulat & Licin & Cembung \\
\hline & S 4 & Hitam & Bulat & Licin & Cembung \\
\hline & S 5 & Hitam & Bulat & Licin & Cembung \\
\hline & S 6 & Hijau dan Hitam & Bulat & Licin & Cembung \\
\hline \multirow{6}{*}{ II } & S 7 & Hijau dan Hitam & Bulat & Licin & Cembung \\
\hline & S 8 & Hijau dan Hitam & Bulat & Licin & Cembung \\
\hline & S 9 & Hijau dan Hitam & Bulat & Licin & Cembung \\
\hline & S 10 & Hijau & Bulat & Licin & Cembung \\
\hline & S 11 & Hijau & Bulat & Licin & Cembung \\
\hline & S 12 & Hitam & Bulat & Licin & Cembung \\
\hline \multirow{6}{*}{ III } & S 13 & Hijau dan Hitam & Bulat & Licin & Cembung \\
\hline & S 14 & Hijau dan Hitam & Bulat & Licin & Cembung \\
\hline & S 15 & Hitam & Bulat & Licin & Cembung \\
\hline & S 16 & Hitam & Bulat & Licin & Cembung \\
\hline & S 17 & Hitam & Bulat & Licin & Cembung \\
\hline & S 18 & Hijau dan Hitam & Bulat & Licin & Cembung \\
\hline
\end{tabular}

Tabel 6. Hasil Uji Biokimia Sampel bakteri E. Coli

\begin{tabular}{|c|c|c|c|c|c|c|c|c|c|c|c|}
\hline \multirow{2}{*}{ Stasiun } & \multirow{2}{*}{ Sampel } & \multirow{2}{*}{ Gram } & \multirow{2}{*}{ Katalase } & \multirow{2}{*}{ Motilitas } & \multirow{2}{*}{ Indol } & \multirow{2}{*}{$\mathrm{H}_{2} \mathrm{~S}$} & \multicolumn{3}{|c|}{ Uji TSIA } & \multirow{2}{*}{ MR } & \multirow[b]{2}{*}{ Sitrat } \\
\hline & & & & & & & G & $\mathbf{L}$ & $\mathbf{S}$ & & \\
\hline \multirow{6}{*}{ I } & S 1 & - & + & + & + & + & $\begin{array}{lll}+ & & \end{array}$ & + & + & + & - \\
\hline & S 2 & - & + & - & + & + & + & + & + & - & + \\
\hline & S 3 & - & + & - & - & + & + & + & + & - & + \\
\hline & S 4 & - & + & + & - & - & + & + & + & - & + \\
\hline & S 5 & - & + & + & - & - & + & + & + & - & + \\
\hline & S 6 & - & + & + & + & + & + & + & + & + & - \\
\hline \multirow{6}{*}{ II } & S 7 & - & + & - & - & + & + & + & + & - & - \\
\hline & S 8 & - & + & - & - & + & + & + & + & - & - \\
\hline & S 9 & - & + & + & + & + & + & + & + & - & + \\
\hline & S 10 & - & + & + & + & + & + & + & + & - & + \\
\hline & S 11 & - & + & + & + & + & + & + & + & - & + \\
\hline & S 12 & - & + & + & + & - & + & + & + & - & - \\
\hline \multirow{6}{*}{ III } & S 13 & - & + & + & - & - & + & + & + & + & + \\
\hline & S 14 & - & + & - & - & - & + & + & + & + & + \\
\hline & S 15 & - & + & - & + & + & + & + & + & + & - \\
\hline & S 16 & - & + & - & - & + & + & + & + & - & - \\
\hline & S 17 & - & + & + & + & + & + & + & + & - & + \\
\hline & S 18 & - & + & + & + & + & + & + & + & - & + \\
\hline
\end{tabular}

Bakteri E. coli ditanam pada media Eosin Methylene Blue Agar (EMB) karena media ini dipilih untuk bakteri Gram negatif. Dari hasil pengamatan, koloni berbentuk batang pendek dan termasuk Gram negatif. Hasil penelitian terdahulu yang dilakukan oleh [20] membuktikan bahwa koloni yang berbentuk bulat, berwarna kekuningan, dengan tepi rata dan permukaan timbul termasuk bakteri Gram negatif.

EMB Agar adalah media selektif dan media diferensial. Warna media sebelum pemupukan bakteri berwarna merah keunguan. Media ini mengandung Eosin dan metilen biru, yang menghambat pertumbuhan bakteri Gram positif, maka media ini dipilih untuk bakteri Gram negatif. Kadar asam yang tinggi dapat 
mengendapkan methylen blue dalam media EMBA [20].

Pada uji katalase, bakteri E. coli menghasilkan nilai positif (+) ditandai dengan adanya gelembung $\mathrm{O}_{2}$. Menurut penelitian yang dilakukan oleh [21] uji katalase dilakukan untuk mengetahui apakah bakteri tersebut merupakan bakteri aerob atau anaerob obligat. Hasil uji indol dalam penelitian ini didapat 10 sampel bersifat positif dan 8 sampel bersifat negatif, uji indol pada sampel bakteri E.coli adalah positif yang ditunjukan adanya cincin merah pada bagian atas setelah ditetesi reagen kovac's yang mengandung P-dimetilaminobenzaldehid, alkohol dan $\mathrm{HCl}$ pekat maka terbentuk cincin merah. Hal ini merupakan hasil dari pemecahan asam amino triptofan oleh bakteri E. Coli [22].

Hasil pengamatan uji motilitas pada E. coli dari 18 sampel didapatkan 11 sampel bersifat positif dan 7 sampel bersifat negatif. Pergerakan dari bakteri tersebut dikarenakan media semisolid (uji motilitas) dirancang dengan mengurangi konsentrasi agar pada media yaitu sekitar $0,4 \%$ pada media yang hanya cukup untuk mempertahankan bentuknya sementara memungkinkan pergerakan bakteri bergerak [23].

Pada media TSIA ini semua media berwarna kuning, hal ini menunjukan bahwa warna kuning pada keseluruhan media tersebut dikarenakan E. coli pada media TSIA dapat memfermentasikan glukosa, laktosa dan sukrosa. Hal ini sesuai pendapat [23] gas positif dikarenakan gas yang dihasilkan oleh fermentasi $\mathrm{H}_{2}$ dan $\mathrm{CO}_{2}$, hal ini dapat dilihat dari pecah dan terangkat agar.

Uji $\mathrm{H}_{2} \mathrm{~S}$ juga menggunakan media

TSIA. Pada uji $\mathrm{H}_{2} \mathrm{~S} 13$ sampel bersifat positif dan 5 sampel bersifat negatif. Hal ini menunjukan bahwa sebagian besar bakteri E. coli mampu memisahkan belerang dari suatu molekul (desulfurasi) asam amino yang menghasilkan $\mathrm{H}_{2} \mathrm{~S}$.

Uji sitrat pada penelitian ini didapat 11 sampel bersifat positif dan 7 sampel bersifat negatif. Hasilnya negatif karena $E$. coli tidak dapat dapat menggunakan sitrat sebagai sumber karbon [24].

Hasil pengamatan untuk Uji MR pada penelitian ini adalah 5 sampel bersifat positif dan 13 sampel bersifat negatif, sampel bakteri E. coli positif ditunjukkan dengan larutan berwarna merah

\section{KESIMPULAN DAN SARAN Kesimpulan}

Dari hasil dan pembahasan pada bab sebelumnya, dapat disimpulkan bahwa pada hasil penelitian yang telah dilakukan, jumlah total coliform di perairan Teluk Sirih pada uji penegasan dengan menggunakan media BGLB berkisar antara 75-460 MPN/ml. Hal ini mengindikasikan adanya pencemaran kelompok bakteri coliform di perairan tersebut berdasarkan Keputusan Menteri Negara Lingkungan No. 51 Tahun 2004 tentang Baku Mutu Air Laut level maksimum total bakteri coliform yaitu 1000 MPN/100 ml. Hasil penelitian tersebut menandakan bahwa perairan Teluk Sirih termasuk ke dalam perairan yang kurang baik.

Saran
\[ \text { Pada penelitian selanjutnya, } \]
disarankan kepada peneliti $\begin{array}{r}\text { untuk } \\ \text { mengidentifikasi pengaruh bakteri }\end{array}$
$\begin{aligned} & \text { pencemaran perairan terhadap produk hasil } \\ & \text { tangkapan. }\end{aligned}$

\section{Saran}

disarankan kepada peneliti untuk mengidentifikasi pengaruh bakteri tangkapan.

\section{DAFTAR PUSTAKA}

1. Askar, A.T., M.U.K. Agung, Y. Andriani dan L.P. Yuliadi. (2018). Kelimpahan Bakteri Coliform pada Air Laut, Sedimen dan Foraminifera Jenis Calcarina di Ekosistem 
Terumbu Karang Pulau Pramuka, Kepulauan Seribu, DKI Jakarta. Jurnal Akuatika Indonesia, 3(1): 36-41.

2. Anggraini, R., M. Salim, dan E. Mardiah. (2013). Uji Bakteri Escherichia coli yang Resistan terhadap Antibiotik pada Ikan Kapas-Kapas di Sungai Batang Arau Padang. Jurnal Kimia Unand, 2(2):17-21.

3. Tanjung, M.J.P., D. Yoswaty, dan I. Effendi. (2020). Antibacterial Activities of Soft Coral Extract Lobophytum sp. towards Pathogenic Bacteria (Escherichia coli, Staphylococcus aureus, and Pseudomonas aeruginosa. Jurnal Perikanan dan Kelautan, 25(2): 151-157

4. Cappucino, J.G. dan N. Sherman. (2001). Microbiology a Laboratory Manual. Rockland Community College. State University of New York.

5. Feliatra. (2002). Sebaran Bakteri Escherichia coli di Perairan Muara Sungai Bantan Tengah, Bengkalis, Riau.

6. Willshaw, G.A., T. Cheasty, and H.R. Smith. (2000). Escherichia coli the Microbiological Safety and Quality of Food. Volume 2. Aspen Publishers, Inc. Gaithersburg, Maryland, USA. p1136-1164.

7. Sutiknowati, L.I. (2014). Kualitas Perairan Tambak Udang Berdasar Parameter Mikrobiologi. Jurnal Ilmu dan Teknologi Kelautan Tropis. Pusat Penelitian Oseanografi LIPI, Jakarta. 6(1):157-170.

8. Pelczar, M.J. dan E.C.S. Chan. (2008). Dasar-Dasar Mikrobiologi 1. Jakarta: UI Press.

9. Novriadi, R. (2010). Kualitas Air untuk Budidaya Ikan Laut. Training Penyuluh Dinas Kelautan dan Perikanan Bangka Belitung di Balai Budidaya Laut Batam. Batam.

10. Dwidjoseputro. (1990). Dasar-Dasar Mikrobiologi. Djambatan, Jakarta

11. Wahyuni, E.A. (2013). Studi Karakteristik Bakteri Coliform di Perairan Selat Madura. Prosiding. Seminar Nasional Hasil Penelitian Perikanan dan Kelautan. Jurusan Perikanan, Fakultas Pertanian, UGM. Yogyakarta

12. Salle, A.J. (2013). Fundamental Principles of Bacteriology. 8ed. Harper \& Brothers. $1094 \mathrm{hlm}$

13. Herd, T., J.S. Crowlker dan L.J Cox. (2001). Keamanan Pangan untuk Ahli Gizi. Ringkasan Penyakit yang Ditularkan Makanan. I CD- SEAMEO-GT2-WHO.

14. Prasetyo, E.B., dan A.D. Siswanto. (2013). Variabilitas Horisontal Suhu dan Salinitas di Perairan Selat Madura. Prosiding Seminar Nasional Hasil Penelitian Perikanan dan Kelautan, Fakultas Perikanan dan Ilmu Kelautan, Universitas Diponegoro, Semarang.

15. Karliana, I. (2009). Identifikasi Mikroba Air Laut di Ujung Grenggengan Semenanjung Muria. Jurnal Sigma Epsion, 13(2): 59-63.

16. Siswanto, A.D. (2011). Tingkat Konsentrasi Suspended Solid (TSS) sebagai Indikator Awal Kualitas Perairan di Kabupaten Bangkalan Pasca Jembatan Suramadu. Prosiding Seminar Nasional Biologi. FMIPA. Universitas Negeri Surabaya

17. Widiyanti, N.L.P.M., W.S. Warpala dan A.P. Suryanti. (2017). Parameter Fisik dan Jumlah Perkiraan Terdekat Coliform Air Danau Buyan Desa Pancasari Kecamatan Sukasada Buleleng. Jurnal Sains dan Teknologi, 6(1):178-188.

18. Darmayati, Y., D.H. Kunarso dan Ruyitno. (2009). Dinamika Bakteri Indikator Pencemaran di Perairan Estuari Cisadane. Jurnal Oseanologi dan Limnologi di Indonesia, 35(2): 273-290

19. Cheeptham, N. and Lindquis. (2014). Eosin Methylene Blue Agar. Thompson Rivers University, Canada. 
20. Dagdag, E.A. dan Sukoso. (2015). Isolation and Characterization of A3 and S3 Isolate Thermophilic Bacteria from Lapindo Sidoarjo Mud, East Java. International Journal of ChemTech Research, 8(2):541-548.

21. Hilda, H. (2017). Pola Resistensi Bakteri Staphylococus aureus, Escherichia coli, Pseudomonas aeruginosa terhadap Berbagai Antibiotik. Husada Mahakam: Jurnal Kesehatan, 4(1):11-17.

22. Lewerissa, F. dan M. Kaihena. (2014). Analisis kualitatif Bakteri Coliform dan Fecal Coliform pada Mata Air Desa Saparua Kecamatan Saparua Kabupaten Maluku Tengah. Jurnal Fakultas Matematika dan Ilmu Pengetauan Alam, 4-13.

23. Leboffe, M. J. and B. E. Pierce. (2011). Brief Microbiology Laboratory Theory \& Application $2^{\text {nd }}$ Edition. Englewood: Morton Publishing. $896 \mathrm{hlm}$

24. Fatmawati, U. (2014). Aktifitas Antibakteri Actinomycetes yang Diisolasi dari TPA Putri Cempo Mojosongo Surakarta. In Proceeding Biology Education Conference: Biology, Science, Enviromental, and Learning, 11(1):431-436. 